\title{
A Brief Review on Extra-Pulmonary Tuberculosis
}

\author{
Dr. Himesh Soni ${ }^{1 *}$, Dr. Sarvesh Sharma ${ }^{1}$, Dr. Sudeep Awadhiya ${ }^{2}$
}

${ }^{1}$ D.H.S. Bhopal-India

${ }^{2}$ Dept. of Paediatrics, LN Medical College, Bhopal-India

DOI: $10.36347 /$ sajp.2020.v09i11.001

| Received: 17.10.2020 | Accepted: 31.10.2020 | Published: 05.11.2020

*Corresponding author: Dr. Himesh Soni

Abstract

Review Article

Tuberculosis is an omnipresent, highly contagious chronic granulamatous communicable bacterial infectious disease caused by Mycobacterium tuberculosis and other species of same genera. Tuberculosis usually affects the lungs, but can also affect other parts of the body. The aim of the present review to illustrate the various sites and co-morbidities associated with extra-pulmonary tuberculosis along with their diagnosis and treatment approaches.

Keywords: $M$. tuberculosis, Extra-pulmonary Tuberculosis (EP), sites and co-morbidities \& treatment approaches. Copyright $(\mathcal{C} 2020$ The Author(s): This is an open-access article distributed under the terms of the Creative Commons Attribution 4.0 International License (CC BY-NC 4.0) which permits unrestricted use, distribution, and reproduction in any medium for non-commercial use provided the original author and source are credited.

\section{INTRODUCTION}

Tuberculosis is a omnipresent, highly contagious chronic granulamatous communicable bacterial infectious disease caused by Mycobacterium tuberculosis and other species of same genera. In 1993, the World Health Association confirmed TB a "Global emergency", as approximately one-third of the world population is infected with $M$. tuberculosis. Tuberculosis, which is easily transmitted through the air, already infects 1.9 billion people, and takes the lives of about two million people each year in which up to $25 \%$ of tuberculosis cases present extra-pulmonary association. The situation has been exacerbated because of the presence of several other complicating factors like multi drug resistant tuberculosis and HIVcoinfection. Tuberculosis is a chief cause of death amongst infectious diseases. Furthermore, this reemerging disease has become one of the most important infections affecting human immunodeficiency virus
(HIV)-positive patients worldwide. TB also is becoming increasingly resistant to existing drugs. It is predictable by the World Health Organization (WHO) that more than 2 billion people in the world are infected with Mycobacterium tuberculosis [1]. Mycobacterial infection is a demanding health problem that requires particular attention worldwide. According to WHO classification criteria EP is defined as an infection by M.tuberculosis which affects outside the pulmonary parenchyma including tissues and organ outside. Approximately 20 and $25 \%$ of all TB cases represented EP [2]. The spread of M.tuberculosis bacilli at hematogenous and lymphatic resulted to Extrapulmonary TB [3, 4].

\section{CAUSES AND SYMPTOMS}

human $[5,6]$

Two type of tuberculosis bacilli that affect the

\begin{tabular}{|l|l|}
\hline \multicolumn{1}{|c|}{ Causes } & \multicolumn{1}{c|}{ Symptoms } \\
\hline $\begin{array}{l}\text { Mycobacterium tuberculosis (endemic in man) is } \\
\text { transmitted by inhalation of the organism in droplets }\end{array}$ & $\begin{array}{l}\text { Tuberculosis pleuritis } \\
\text { May occur in 10\% of people who have the lungs disease } \\
\text { from tuberculosis. These people have a non-productive } \\
\text { cough, chest pain and fever. } \\
\text { Miliary tuberculosis } \\
\text { In minority of people with weekend immune } \\
\text { system, tuberculosis bacteria may spread through their } \\
\text { blood to various parts of their } \\
\text { body. The symptom produces fever, weakness, and loss of } \\
\text { appetite. }\end{array}$ \\
\hline
\end{tabular}




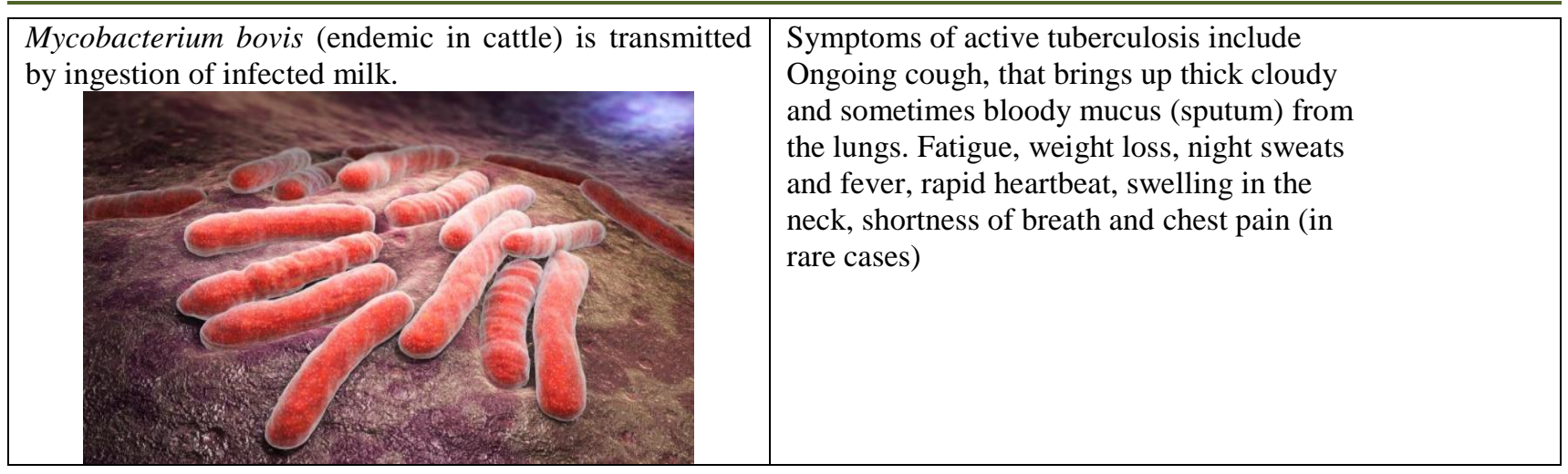

Various type of extra pulmonary Tuberculosis

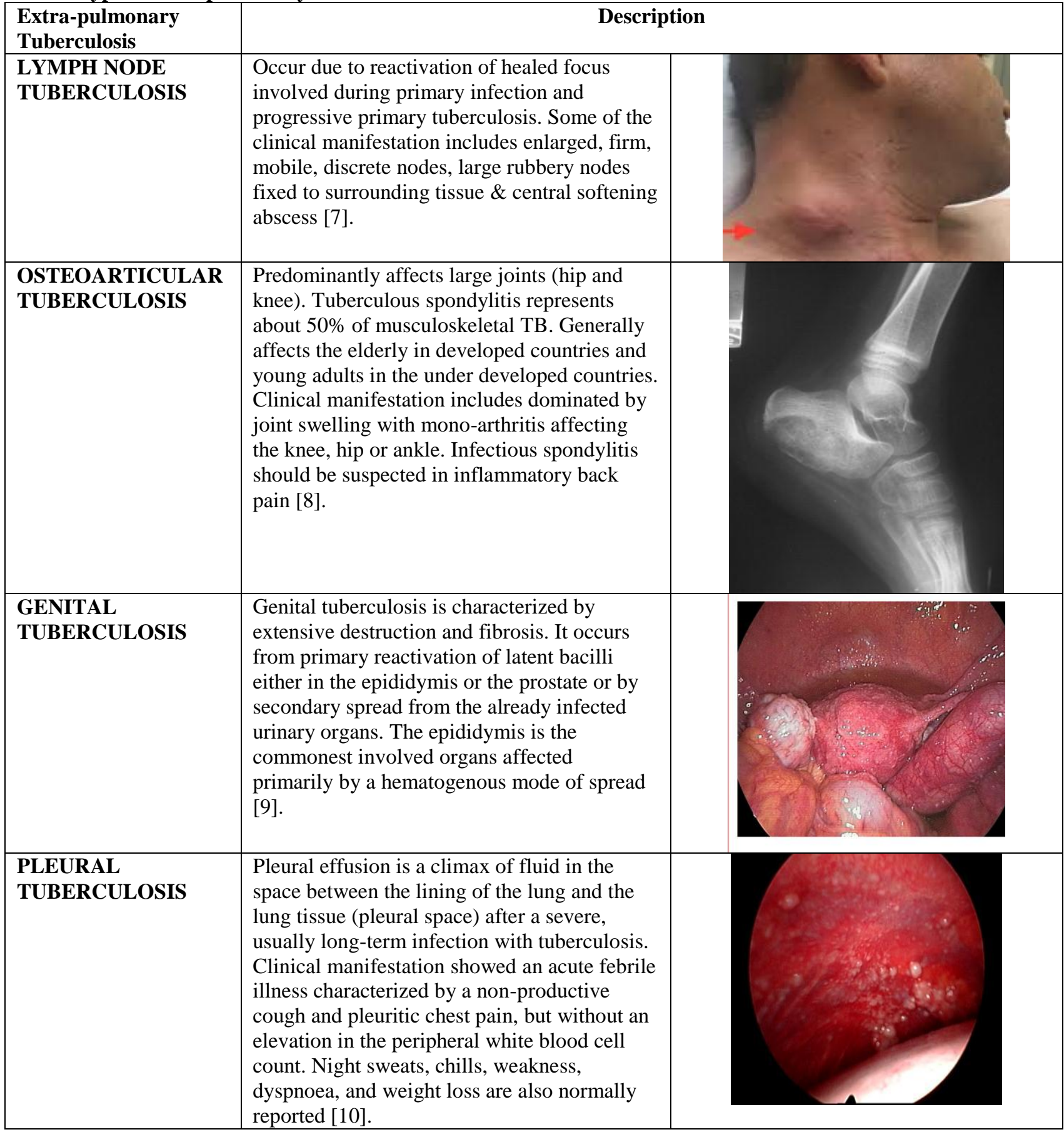




\begin{tabular}{|l|l|l|}
\hline ABDOMINAL & $\begin{array}{l}\text { Mostly affected gut, the peritoneum (the } \\
\text { lining of the abdominal cavity) and abdominal } \\
\text { lymph nodes. The bacilli can be affected the } \\
\text { mucosal layer which lead formation of } \\
\text { epithelioid tubercles in the lymphoid tissue of } \\
\text { the submucosa. Furthur necrosis of tubercles } \\
\text { leads to ulceration [11]. Clinical manifestation } \\
\text { showed abdominal pain, weight loss, anemia, } \\
\text { and fever with night sweats. }\end{array}$ \\
\hline $\begin{array}{l}\text { CENTRAL } \\
\text { TUBERCULOSIS }\end{array}$ & $\begin{array}{l}\text { CNS tuberculosis leads development of small } \\
\text { tuberculous foci (Rich foci) in the brain, } \\
\text { spinal cord, or meninges [12]. Fever, stiff } \\
\text { neck and seizures are some of the common } \\
\text { symptom. }\end{array}$ \\
\hline
\end{tabular}

Major Co-morbidities associated with Tuberculosis
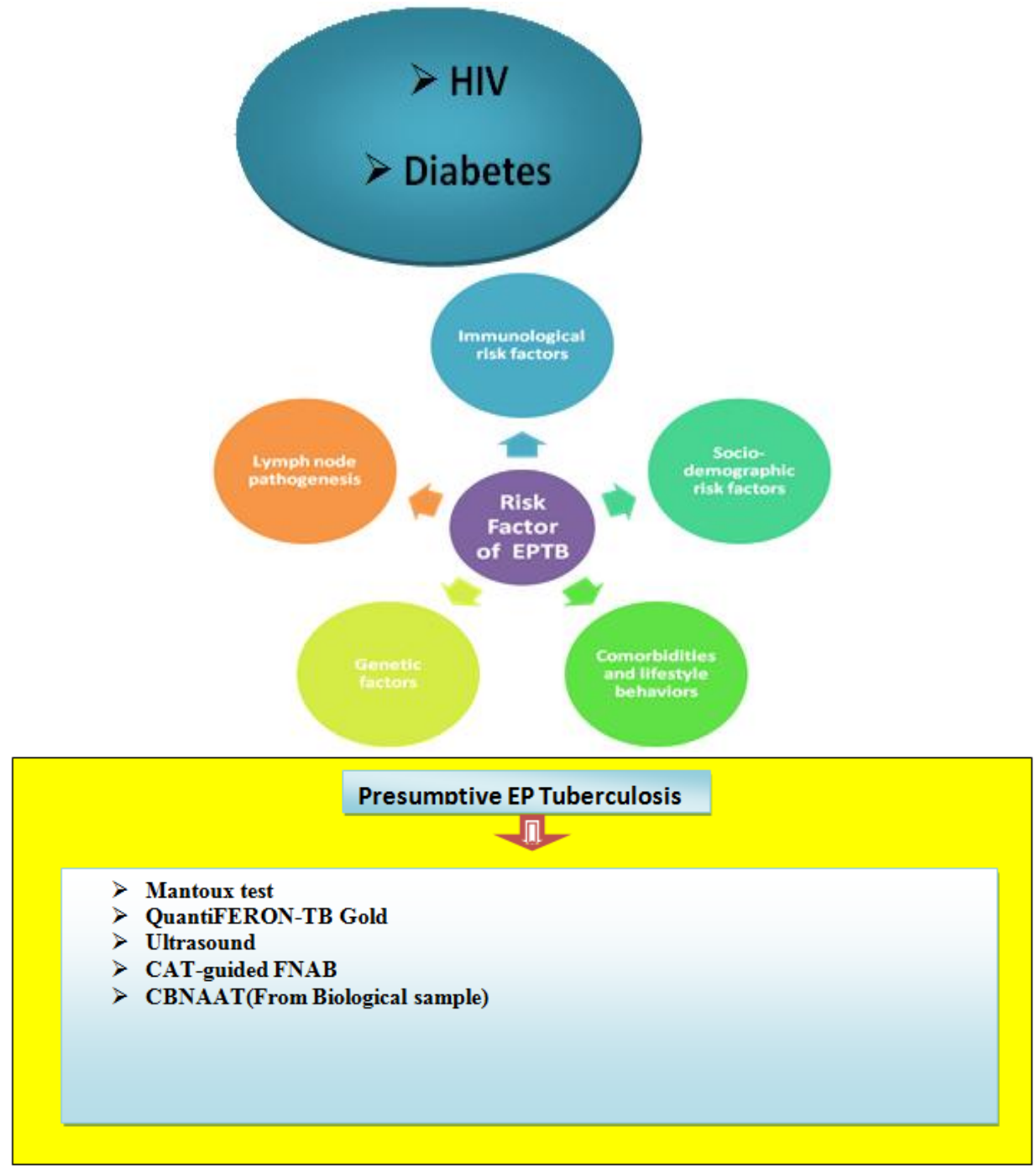


\section{Diagnostic Approaches Extra-pulmonary tuberculosis}

Diagnostic Algorithm of Extrapulmonary Tuberculosis

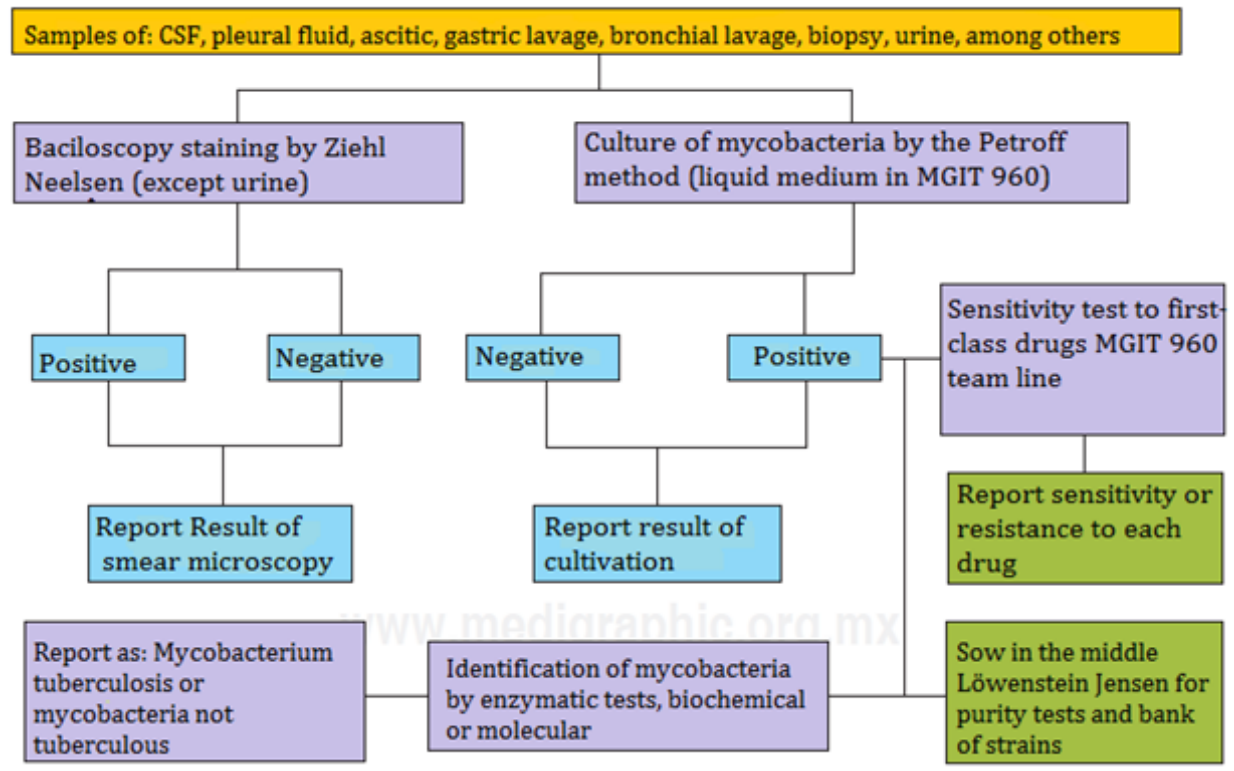

Summary of Symptoms and Investigation tools for various types of EP Tuberculosis

\begin{tabular}{|c|c|c|c|}
\hline S.No. & Type of EP Tuberculosis & Symptom & $\begin{array}{cc}\text { Investigation Tool } \\
\end{array}$ \\
\hline 1. & $\begin{array}{l}\text { Neuro-tuberculosis } \\
\text { (Tuberculoses meningitis) }\end{array}$ & $\begin{array}{l}\text { Lethargy } \\
\text { Seizures } \\
\text { Weight loss } \\
\text { Altered sensation } \\
\text { Vomiting } \\
\text { Diplopia } \\
\text { Giddiness }\end{array}$ & $\begin{array}{l}\text { CSF-Lumbar puncture- Cob web formation } \\
\text { CBNAAT } \\
\text { BACTEC } \\
\text { CSF-IGRA test } \\
\text { TB-Gold test } \\
\text { CT-Scan } \\
\text { MRI scan(Hydrocephalus) }\end{array}$ \\
\hline 2. & Abdominal Tuberculosis & $\begin{array}{l}\text { Constipation } \\
\text { Abdominal pain } \\
\text { Abdominal distension } \\
\text { Weight loss } \\
\text { Vomiting } \\
\text { Ascites }\end{array}$ & $\begin{array}{l}\text { USG(Abdominal) } \\
\text { X-Ray(Abdominal) } \\
\text { TB-Gold test } \\
\text { CT-Scan } \\
\text { Adenine deaminase test } \\
\text { IFN-T level } \\
\text { Laparoscopy } \\
\text { Biopsy }\end{array}$ \\
\hline 3. & Bone Tuberculosis & $\begin{array}{l}\text { Chronic back pain(Pott's spot) } \\
\text { Difficulty in movement } \\
\text { particularly banding forward }\end{array}$ & $\begin{array}{l}\text { X-Ray(Spine) } \\
\text { MRI scan(Spine) } \\
\text { XPERT } \\
\text { CBNAAT } \\
\text { CT scan }\end{array}$ \\
\hline 4. & TB lympadenitis & $\begin{array}{l}\text { Painless } \\
\text { Swelling on cocrial vertical \& } \\
\text { horizontal } \\
\text { chain of lymph node } \\
\text { Fever } \\
\text { weight loss } \\
\text { chronic discharging sinus } \\
\end{array}$ & $\begin{array}{l}\text { Biopsy } \\
\text { Histopathology of affected Lymph node } \\
\text { PCR } \\
\text { Aspiration cytology }\end{array}$ \\
\hline 5. & Renal Tuberculosis & $\begin{array}{l}\text { Painless } \\
\text { hematuria }\end{array}$ & $\begin{array}{l}\text { PCR } \\
\text { U-culture in AFB } \\
\text { TB-Gold test }\end{array}$ \\
\hline 6. & TB Pericaditis/ & $\begin{array}{l}\text { Chest } \\
\text { Fever dysplasia } \\
\text { Weight loss }\end{array}$ & $\begin{array}{l}\text { Aspiration fluid } \\
\text { ADA }>40 \mu / L \\
\text { Cytology }\end{array}$ \\
\hline 7. & Pleural effusion & $\begin{array}{l}\text { Pain on breathing } \\
\text { cough } \\
\text { Febrile } \\
\text { dysplasia }\end{array}$ & Fluid Aspiration \& Cytology \\
\hline
\end{tabular}




\section{Treatment Approach}

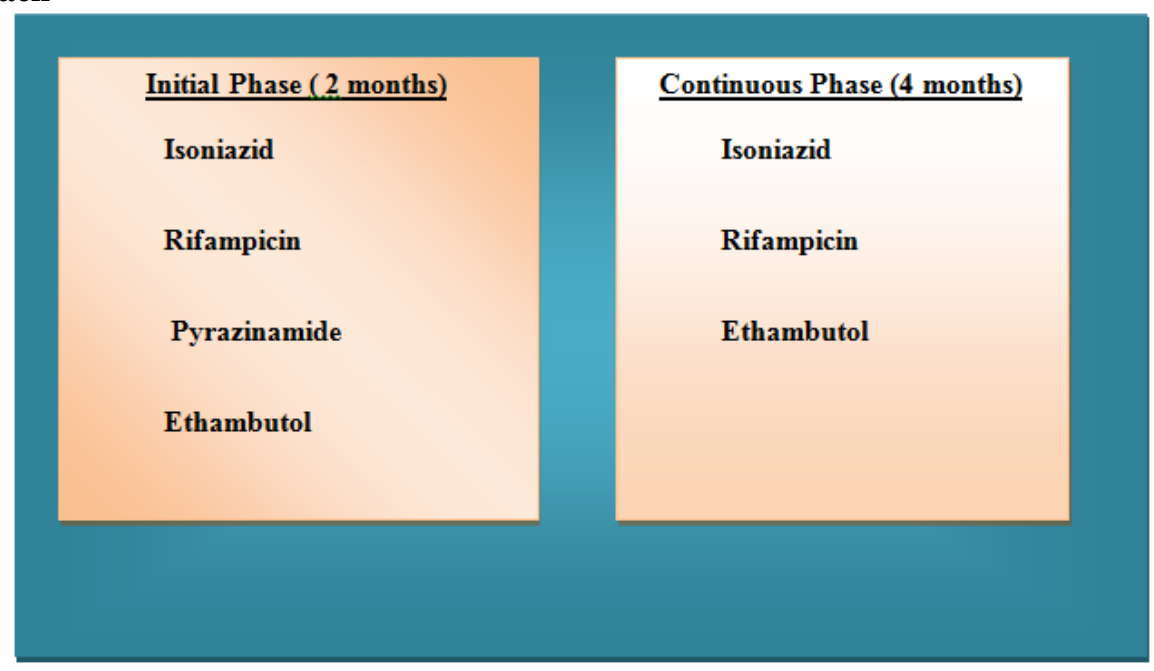

1. Treatment of individuals with active tuberculosis (TB) is the first priority for TB control; but an important second priority is identification and treatment of individuals with latent tuberculosis in order to avoid the disease dissemination.

2. The WHO recommends that chemoprophylaxis of these patients must be included as

3. Part of the TB control program for high income or upper middle-income countries with an estimated TB incidence rate of less than 100 per 100,000 populations per year.

4. For treatment of latent tuberculosis infection in HIV-uninfected adults, the WHO suggested either nine months of selfadministered Isoniazid (INH) or three months of weekly INH and Rifapentine (RPT), preferably administered via directly observed therapy. Alternative regimens include daily INH for six months, daily Rifampin (RIF) for four months, or daily INH and RIF for three months. For HIV-infected patients with latent TBC, they are significantly more likely to reactivate with TB disease than HIVuninfected individuals.

5. Treatment of latent TB is associated with two important benefits:
I. Reduction in the likelihood of progression to active TB disease,
II. Reduction in TB transmission.

Chemoprophylaxis is warranted for HIVinfected patients in the following circumstances: Individuals with recent contact with a person with active TB disease, individuals with a history of inadequately treated healed TB (fibrotic disease on chest radiograph), regardless of test results for latent $\mathrm{TB}$, individuals with evidence of latent $\mathrm{TB}$ by tuberculin skin test or interferon-gamma release assay and individuals living in resource-limited areas of high
TB incidence where testing for latent $\mathrm{TB}$ is not available

\section{CONCLUSION}

Despite the availability of a restore to health and acquaintance on prevention of transmission, EPTB remains a imperative public health problem for a noteworthy proportion of the world. In developing countries, EPTB is less well addressed by programs than PTB, while its identification is imperative for optimizing care. Therefore, investigate EPTB determinants and identifying patients at higher risk of EPTB involvement is immediately needed in order to improve TB management and to ameliorate the diseases prognosis. TB spreading and acquiring EPTB form depend on a huge number of factors: Comorbidities, HIV-coinfection, host factors, genetic variance and the site of the infection. Given the current shocking rates of EPTB burden, elimination of the disease at global level is still out of reach. Therefore, prevention of TB spreading must be a public health priority worldwide and immense resource investment is required. Poverty reduction has been emphasized by the United Nations as a tool to reduce TB burden. The key towards achieving the STOP TB target of global TB eradication by 2050 will be sustained commitment from donors, authorities, effective national TB programs as well as community engagement, which played a fundamental role in identifying the most susceptible groups, assessing their specific needs and promoting good quality of life for TB patients.

Concern of Extra pulmonary can occur in isolation or along with a pulmonary focus as in the case of patients with disseminated tuberculosis (TB). The current human immunodeficiency virus (HIV) and acquired immunodeficiency syndrome (AIDS) pandemic has resulted in changing epidemiology and has once again brought extra pulmonary tuberculosis (EPTB) into focus. EPTB constitute about $15-20 \%$ of 
all cases of tuberculosis in immunocompetent patients and accounts for more than $50 \%$ of the cases in HIVpositive individuals. Lymph nodes are the most common site, followed by pleural effusion and virtually every site of the body can be affected. Since the clinical presentation of EPTB is a typical, tissue samples for the evidence of diagnosis can sometimes be not easy to procure, and the conventional diagnostic methods have a poor yield, the diagnosis is often delayed. Availability of computerised tomographic (CT) scan, magnetic resonance imaging (MRI) laparoscopy, endoscopy has tremendously helped in anatomical localization of EPTB. The disease usually responds to standard antituberculosis drug treatment. Biopsy and/or surgery are required to procure tissue samples for diagnosis and managing the complications. Further research is required for evolving the most suitable treatment for EPTB.

\section{REFERENCE}

1. Andrea T. Cruz Paula A. Revell Jeffrey R. Starke. Gastric Aspirate Yield for Children with Suspected Pulmonary Tuberculosis. Journal of the Pediatric Infectious Diseases Society.2013; 2(2): 171-174.

2. Who report? Global Tuberculosis control: epidemiología, strategy, finances. Geneva: World Health; 2009.

3. Fisher D, Elwood K. Nonrespiratory tuberculosis. In: Canadian Thoracic Society, Canadian Lung Association, and the Public Health Agency of
Canada, editors. Canadian Tuberculosis Standards. 7th Edition. Ottawa: Canadian Thoracic Society; 2013.

4. Himesh Soni. Spoligotyping of Mycobacterium tuberculosis strains from Ziehl-Neelsen stained sputum slides from DTC, Satna (MP). International Journal of Research in Pharmaceutical and Biomedical Sciences. 2010; 1(2): 97-101.

5. Tortora. Microbiology. 2004.

6. Potter Beth, Rindfleisch Kirsten and Krauss K Connie. Management of Active Tuberculosis, American Family Physician. 2005; 72:11.

7. Avinash Gandhare. Tuberculosis of the lymph nodes: Many facets, many hues. THE extrapulmonary disease - the big dilemma. 4 ; 2(8).

8. Zeineb Alaya. Osteoarticular Tuberculosis: Clinical and Therapeutic Feature. MOJ Orthop Rheumatol. 2016, 4(5): 00149.

9. Siddharth Yadav. Genital tuberculosis: current status of diagnosis and management.TAU. 2017; 6; 2.

10. Morné J. Vorster. Tuberculous pleural effusions: advances and controversies. J Thorac Dis. 2015 Jun; 7(6): 981-991.

11. Uma Debi. Abdominal tuberculosis of the gastrointestinal tract: Revisited. World J Gastroenterol. 2014 Oct 28; 20(40): 14831-14840.

12. Bryan Rock R. Central Nervous System Tuberculosis: Pathogenesis and Clinical Aspects. Clin Microbiol Rev. 2008 Apr; 21(2): 243-261. 